\title{
Human T-cell Lymphotropic Virus types I and II (HTLV-I/II) in French Guiana: clinical and molecular epidemiology
}

\author{
Os Vírus T-Linfotrópicos Humanos tipo I \\ (HTLV-I) e tipo II (HTLV-II) na Guiana Francesa: \\ epidemiologia clínica e molecular
}

Mirdad Kazanji 1,2

Antoine Gessain 2

\footnotetext{
${ }^{1}$ Laboratoire

de Rétrovirologie,

Institut Pasteur de la Guyane. B.P. 6010 ,

23 Avenue Pasteur, 97300

Cayenne, French Guiana.

mkazanji@pasteur-cayenne.fr

2 Unité d'Epidémiologie

et de Physiopathologie

des Virus Oncogènes,

Institut Pasteur. 25-28

Rue de Dr. Roux, 75015

Paris, France.
}

\begin{abstract}
We review here the epidemiological studies performed by our group on human retrovirus HTLV-I and HTLV-II infections and the associated diseases in French Guiana since 1984. French Guiana is an overseas French administrative district located between Brazil and Surinam. Its population is characterized by a large variety of ethnic groups, including several populations of African origin and various populations of Amerindian origin. Several epidemiological studies of large samples of pregnant women and in remote villages showed that HTLV-I is highly endemic in this area but is restricted to groups of African origin, especially the Noir-Marrons. In this endemic population, the results of segregation analysis in a genetic epidemiological study were consistent with the presence of a dominant major gene predisposing to HTLV-I infection, especially in children. In contrast, HTLV-II infection appears to be rare in French Guiana, having been found in only a few individuals of Brazilian origin. From a molecular point of view, the HTLV-I strains present in the Noir-Marrons, Creoles and Amerindians appear to originate from Africa, as they belong to the large cosmopolitan molecular subtype A.
\end{abstract}

Key words Retroviridae; HTLV-I; HTLV-II; Genetic Variability; T-cell Leukemia

Resumo Os autores apresentam uma revisão dos estudos epidemiológicos realizados pelo seu grupo de pesquisa sobre a infecção pelos vírus T-linfotrópicos humanos tipo I (HTLV-I) e tipo II (HTLV-II) e doenças associadas na Guiana Francesa, desde 1984. A Guiana Francesa é um Departamento de Ultramar da França, situado entre o Brasil e o Suriname. A população é caracterizada por uma grande variedade de grupos étnicos, incluindo diversas comunidades de origem africana e outras de origem indígena. Diversos inquéritos epidemiológicos sobre gestantes e em aldeias remotas mostraram que o HTLV-I é altamente endêmico nessas áreas, mas que o vírus é restrito a grupos de origem africana, particularmente os Noir-Marrons. Nessa população endêmica, os resultados de uma análise de segregação num estudo epidemiológico genético eram coerentes com a presença de um gene maior dominante determinando a predisposição para a infecção pelo HTLV-I, especialmente em crianças. Por outro lado, a infecção pelo HTLV-II parece ser rara na Guiana Francesa, tendo sido encontrada apenas em alguns indivíduos de origem brasileira. Do ponto de vista molecular, as cepas de HTLV-I presentes entre os Noir-Marrons, Creoles e indígenas parecem ser originárias da África, uma vez que pertencem ao grande genótipo cosmopolita, ou sub-grupo molecular A.

Palavras-chave Retroviridae; HTLV-I; HTLV-II; Variação Genética; Leucemia de Células T 


\section{Human T-cell Lymphotropic Viruses, types I (HTLV-I) and type II (HTLV-II)}

The human T-cell lymphotropic viruses type I (HTLV-I) and II (HTLV-II) are members of a group of mammalian retroviruses with similar biological properties and tropism for $\mathrm{T}$ lymphocytes. HTLV-I is the causative agent of adult T cell leukemia/lymphoma (ATL) (Poiesz et al., 1980) and tropical spastic paraparesis/HTLV-Iassociated myelopathy (TSP/HAM) (Gessain et al., 1985). It has also been associated with a variety of other syndromes, including infectious dermatitis in children (Lagrenade et al., 1990) and uveitis (Mochizuki et al., 1992), and to a lesser extent with arthropathy (Ijichi et al., 1990) and polymyositis (Morgan et al., 1989). HTLV-II may be responsible for neurological syndromes that are clinically similar to TSP/ HAM (Hjelle et al., 1992; Murphy et al., 1997), but no hematological disorders have been definitely linked to infection with this virus (Fouchard et al., 1995; Hjelle et al., 1991).

HTLV-I is not ubiquitous but is endemic in some geographical areas and among some ethnic groups. High HTLV-I seroprevalence rates ( $>2 \%$ in the adult population) have been described in Southern Japan, sub-Saharan Africa, the Caribbean Basin, parts of South America, and some areas of Melanesia and the Middle East (Gessain, 1996) where 15-20 million people are infected with this virus. An HTLV-I-associated disease will develop in 3-8\% of these infected individuals once in their lifetime (de The \& Bomford, 1993; Gessain, 1996).

HTLV-II has been shown to be endemic among various American Indian populations, including Navajos and Pueblos (New Mexico) (Hjelle et al., 1993) and Seminoles (Florida) (Biggar et al., 1996; Levine et al., 1993) in North America and the Guaymi in Panama (Lairmore et al., 1990; Pardi et al., 1993). In South America, a number of distinct populations in Colombia (Wayu, Guahibo, and Tunebo groups) (Ijichi et al., 1993; Switzer et al., 1995), Argentina (Toba and Mataco) (Biglione et al., 1999), and Brazil (Kayapó and Krahô) (Black et al., 1994; Hall et al., 1996; Shindo et al., 2002) have been found to be infected with this virus. HTLV-II infection has also been endemic for the past $10-20$ years among intravenous drug users in Europe, especially in Italy (Salemi et al., 1998), Spain (Soriano et al., 1993), and Ireland, as well as in North America (Hall et al., 1992; Lee et al., 1989; Murphy et al., 1998; Schwebke et al., 1994).

HTLV-I and HTLV-II can be transmitted in three ways: mother-to-child transmission (associated mainly with prolonged breastfeeding), mainly in tropical developing countries; sexual transmission (mainly from men to women); and parenteral transmission (by needle sharing and transfusion). In every endemic population, there is an increase in HTLV-I seroprevalence with age, especially among women.

In Latin America, high HTLV-I endemicity is found mainly in populations of African ancestry but also, in some rare cases, among populations of Japanese origin. HTLV-I is thus very rare in Amerindians, in contrast to the situation with HTLV-II. HTLV-I seroprevalence rates ranging from 1 to $10 \%$ are found in the adult populations of some groups in Argentina, Brazil, Colombia, Peru, and several Caribbean countries, including Guadeloupe, Jamaica, Martinique, and Trinidad and Tobago (Gessain, 1996; Gotuzzo et al., 2000).

French Guiana is an overseas French administrative district located in the Amazonian forest complex on the northeast coast of the South American continent, between Brazil and Surinam (Figure 1). Tropical rainforest comprises $90 \%$ of its surface of $91,000 \mathrm{~km}^{2}$, the remaining $10 \%$, in the northern part of the country, being a littoral plain where $90 \%$ of the 136,000 inhabitants live. The population is made up of a large variety of ethnic groups, including Creoles (50\%), who are of mixed European and African descent, Amerindians (4\%), Noirs-Marrons (5.4\%), immigrants from Haiti (20\%), Brazil (4.3\%), and various Asian countries (Hmong Chinese) (2.1\%), and whites, mainly from metropolitan France (14.2\%) (according to the 1990 census). Since 1983, we have undertaken in French Guiana a number of clinical and molecular epidemiological studies of HTLV-I and HTLV-II infection and associated diseases, and this review presents a brief overview of the results of these long-term studies.

\section{French Guiana, an area of high endemicity for HTLV-I in South America}

In 1984, Gessain et al. used an ELISA to determine the prevalence of HTLV-I antibodies in various ethnic groups in French Guiana, consisting of 135 blood donors in Cayenne, 97 NoirMarrons and 57 Wayana Indians from the Maripasoula area, and 57 Hmong from Cacao village (Figure 1). They found a significant difference in HTLV-I seroprevalence between NoirMarrons and Wayana Indians, with $10.3 \%$ and $0 \%$ respectively, as determined by high antibody titers directed against HTLV- 1 antigens. These results strongly suggested that HTLV-I was highly endemic among Noirs-Marrons (de 
The et al., 1985; Gessain et al., 1984). After this initial sero-epidemiological study, a number of studies were conducted on this population, who live mainly on the right bank of the Marroni River, including the main town of Saint Laurent du Maroni and several villages, such as Maripasoula and Papaichton (Figure 1).

In order to determine the main epidemiological characteristics of HTLV-I infection in this population, Plancoulaine et al. (1998) evaluated the prevalence of HTLV-I infection in Maripasoula village. Plasma samples from 1614 persons (83.2\% of the population) aged 2-91 years (mean age, 21) were screened for HTLVI with an ELISA and an immunofluorescence test (IFA) (on MT2 cells), and positive samples were tested by an HTLV-I and -II type-specific Western blot method. The overall HTLV-I seroprevalence in this village was $6.7 \%$, but infection was restricted to members of only three (all of African ancestry) of the six ethnic groups living in the area: mainly Noir-Marrons (8\%), but also Creoles (4.1\%) and individuals of mixed Noir-Marron and other ethnic groups (3.6\%). Among purely Noir-Marron individuals (1,222 persons: 606 male and 616 female), who represented $76 \%$ of those tested, HTLV-I seroprevalence increased significantly with age, reaching $40 \%$ in women over 50 years of age (Figure 2). The univariate risk factors for HTLVI seropositivity in women included older age, more pregnancies, more live births, and a history of hospitalization. A cross-sectional analysis of sexual partners demonstrated an excess of discordant female HTLV-I+/male HTLV-Icouples, indicating preferential male-to-female sexual transmission. The finding of 11 HTLV-I-seropositive children under 15 years of age, of whom nine had an HTLV-I seropositive mother, suggested continuing mother-to-child transmission. These results confirmed the high seroprevalence of HTLV-I in this area, especially in the Noir-Marron population, which is probably due to the high rates of mother-to-child and sexual transmission within this rather isolated group of African origin.

To investigate whether familial aggregation of HTLV-I infection (as determined by specific seropositive status) could be explained in part by genetic factors, Plancoulaine et al. (2000) conducted a large genetic epidemiological survey in the same area. All the families in the villages of Maripasoula and Papaichton were included, representing 1,638 subjects in 83 pedigrees, of whom 165 (10.1\%) were HTLV-I seropositive. The results of the segregation analysis were consistent with the presence of a potential dominant major gene predisposing
Figure 1

Map of French Guiana with the localities in which epidemiological

studies have been conducted.

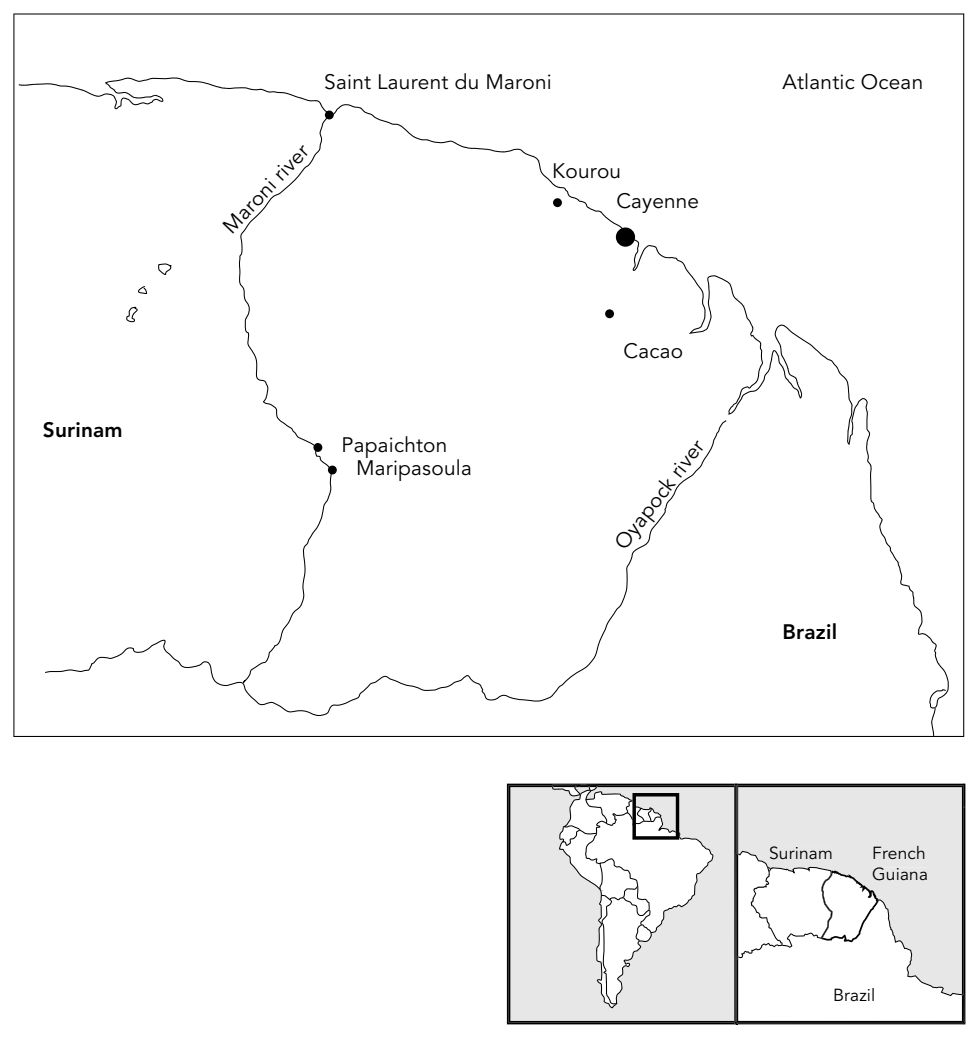

to HTLV-I infection, in addition to the expected familial correlations (mother-offspring, spousespouse) due to virus transmission. In this genetic model, approximately $1.5 \%$ of the population is predicted to be highly predisposed to HTLV-I infection, and almost all the seropositive children under 10 years of age are genetic cases, whereas most HTLV-I seropositive adults are sporadic cases. Ongoing studies based on genomic screening of individuals in the most informative families and linkage analysis are being conducted to characterize the potential genes at the molecular level.

\section{HTLV-I in pregnant women and mother-to-child transmission in French Guiana}

Several studies have been conducted to assess the prevalence and incidence of HTLV-I among 
Figure 2

Age- and sex-dependent HTLV-1 seroprevalence rates in 1,638 Noir-Marrons (878 women and 760 men)

in the villages of Maripasoula and Papaichton, French Guiana.

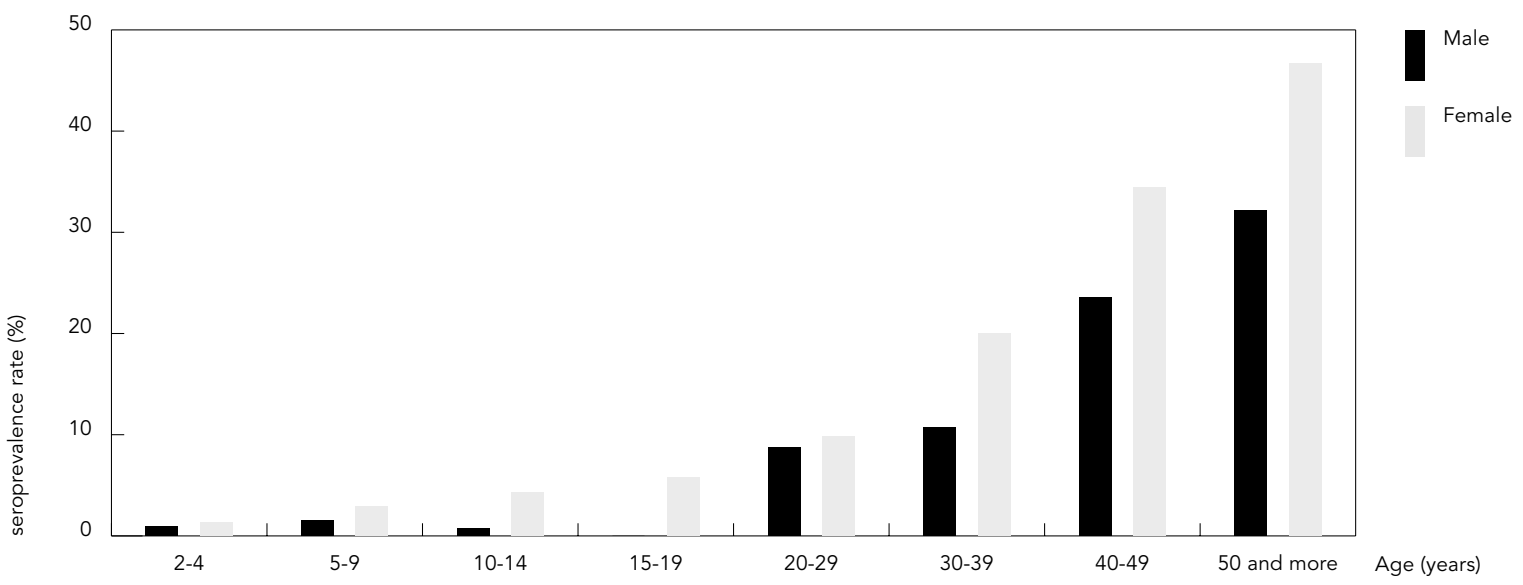

Modified from Plancoulaine et al. (1998).

pregnant women belonging to different ethnic groups in French Guiana (Tortevoye et al., 2000; Tuppin et al., 1995). The 4,234 pregnant women who delivered between 1991 and 1997 in Saint Laurent du Maroni, an area of high HTLV-I endemicity, were studied initially. HTLV-I was significantly more prevalent among Noir-Marron $(4.8 \%)$ and Haitian $(5 \%)$ women than among Amerindians $(0 \%)$, Creoles $(0 \%)$ or Hmongs $(0 \%)$. An age-dependence of HTLV-I seroprevalence was observed, the mean age of Noir-Marron HTLV-I seronegative women being lower than that of the seropositive women (24. $7 \mathrm{vs}$. 28.6) ( $\mathrm{p}<0.001$ ) (Tortevoye et al., 2000). A decline in HTLV-I seroprevalence with age was observed, particularly among Noir-Marron women under 21 years of age. These data strongly suggest, for the first time outside Japan, a birth cohort effect for HTLV-I in an ethnic group with high endemicity. These studies, which now include a 10-year follow-up of more than 6,000 pregnant women, are still ongoing.

In order to gain new insight into the risk factors for mother-to-child transmission of HTLVI, a retrospective study was conducted among children born to HTLV-I seropositive Noir-Marron women (Ureta-Vidal et al., 1999). The study covered 81 HTLV-I-seropositive mothers and their 216 children aged 18 months to 12 years. Of the 216 children, 21 were HTLV-I-seropositive, giving a crude transmission rate of $9.7 \%$; of the 180 breastfed children, $10.6 \%$ were HTLV-
I-seropositive. Complete concordance was observed between the serological results and the presence of HTLV-I provirus, as detected by polymerase chain reaction (PCR), and none of the 195 HTLV-I-negative children was found to be HTLV-I-positive by PCR. In conditional (by family) logistic-regression models, the authors showed that HTLV-I seropositivity in children was associated with an elevated maternal HTLVI-antibody titer, a high maternal HTLV-I proviral load and, surprisingly, the child's sex, girls being more frequently infected than boys.

\section{HTLV-I and HTLV-II in Amerindians in French Guiana}

While HTLV-I infection among the Noir-Marron and Creole populations of French Guiana was well documented, little was known about HTLV-I/II infection among Amerindians in this area. In 1997, Talarmin et al. (1999) performed a serological study to evaluate the prevalence of HTLV infections in the six Amerindian tribes, comprising about 4,900 individuals, living in French Guiana: the Galibi and Wayana belonging to the Karib linguistic family and related to many tribes located between the Amazon and Orinoco rivers; the Palikur and Arawak belonging to the Arawak linguistic family, which is scattered throughout the Amazon Basin; and the Wayampi and Emerillon of the Tupi-Guarani 
linguistic family, which are northern tribes of an ethnic group which came from southern Brazil and Paraguay. Currently, the Galibis live along the west coast of French Guiana and the Palikurs along the east coast. The Arawaks live near Cayenne and Saint-Laurent du Maroni, whereas the Wayanas are scattered along the Maroni River, and the Wayampis live in two villages in the Haut-Oyapock region. The Emerillons live along both rivers (Grenand \& Grenand, 1990).

A total of 847 sera from 545 Amerindian women and 302 Amerindian men were tested for antibodies to HTLV-I and II. While no HTLVII-specific antibodies were detected, five women $(0.59 \%)$ had antibodies directed against HTLVI. The rates of infection with HTLV-I differed among the groups: Arawaks, 1/54 (1.8\%); Galibis, 0/136; Palikurs, 2/78 (2.6\%); Emerillons, 0/56; Wayanas, 0/385; and Wayampis, 2/138 (1.4\%). A family survey conducted among the relatives of the two Wayampi women who were infected with HTLV-I indicated that their mothers were not infected with HTLV-I (Talarmin et al., 1999). HTLV-II was detected for the first time in Cayenne in 1998, in a 51-year-old Brazilian woman admitted to hospital for chronic renal failure first diagnosed in 1993. A screening serological test was positive, and a Western blot showed strong reactivity to rgp21, p24, and rgp46-II (K55) with a weaker reactivity to p19, strongly indicating HTLV-II infection. This woman, of Amerindian origin, had emigrated from Belém, Brazil, 21 years previously. She had worked as a prostitute in Brazil, but not in French Guiana, and had never used intravenous drugs. The Western blot profile of another Brazilian woman admitted to Cayenne Hospital was also consistent with HTLV-II infection. These observations suggested that HTLV-II was present essentially in the Brazilian population living in French Guiana and raised the possibility of an increased risk for HTLV-II infection in the future in view of the continuing high rate of immigration into French Guiana from Brazil. Thus, a new serological study was conducted to evaluate HTLV-II seroprevalence in the Brazilian population of French Guiana. None of 247 sera tested, including 72 from prostitutes, was HTLV-II-positive, but three were HTLV-I-positive and four were indeterminate (Kazanji et al., 2001). These sero-epidemiological studies indicated that HTLV-II infection is still rare in French Guiana and unlikely to become prevalent in the near future.

\section{Molecular epidemiology of HTLV-I and HTLV-II in French Guiana}

Recent molecular studies on HTLV-I have demonstrated the genetic stability of the virus and the existence of several molecular subtypes (genotypes), which were related to the geographical origin of the infected populations and not to the associated diseases (Slattery et al., 1999). Use of viral amplification by clonal expansion of infected cells, rather than by reverse transcription, could explain this remarkable genetic stability, which can be used as a basis for gaining new insights into the origin, evolution, and modes of dissemination of HTLV-I. On the basis of a comparison of the sequences and phylogenetic analyses of the gp21 env gene and the long terminal repeat (LTR) region, four major geographical genotypes have been described: Cosmopolitan, HTLV-I subtype A; Central African, HTLV-I subtype B; Melanesian, HTLV-I subtype C; and HTLV-I subtype D. Furthermore, within subtype A, four main subgroups could be distinguished: a transcontinental, a West African, a North African, and a Japanese subgroup (Gessain et al., 2002).

Analyses of HTLV-I and STLV-I (its simian counterpart) viral strains throughout the world suggest that four events are responsible for the current observed pattern of dissemination: (1) the probable transmission of STLV-I between simian species; (2) transmission of STLV-I to humans, as exemplified by the high homology between STLV-I strains from chimpanzees or mandrills and some HTLV-I from inhabitants of Central Africa; (3) persistence of HTLV-I by sexual and mother-to-child transmission in remote populations, as seen in the AustraloMelanesian region; and (4) global distribution of HTLV-I via large-scale human migration, such as the slave trade from Africa to the New World.

The two main known molecular subtypes of HTLV-II (HTLV-IIA and HTLV-IIB) have been found in both Amerindians and intravenous drug users, but HTLV-II subtype B, prevalent mainly in Amerindian groups, is often referred to as the paleo-Indian subtype (Dube et al., 1993; Eiraku et al., 1996; Gessain et al., 2002; Lee et al., 1993; Switzer et al., 1996).

In order to determine the origin and the modes of dissemination of these viruses in French Guiana, we undertook molecular characterization of some HTLV-I and HTLV-II strains from various ethnic groups living in this area (Kazanji et al., 2001; Talarmin et al., 1999).

For HTLV-I, a 522-bp portion of the gp21 $e n v$ gene was obtained by PCR from peripheral 
blood mononuclear cell DNA from five HTLV-Iinfected Creoles, five Noir-Marrons, and four Amerindians. In order to confirm the genomic subtype of the HTLV-I strains, the complete LTR (755bp) was sequenced for one member of each ethnic group. Analysis of the nucleotide sequences showed that all the HTLV-I strains were similar to the cosmopolitan subtype A prototype ATK strain, the similarities being slightly stronger between Amerindian and Creole strains than between Amerindian and NoirMarron strains or between Creole and NoirMarron strains. In a phylogenetic analysis of the gp21 env gene of 60 HTLV-I sequences, including the new strains from French Guiana and the main prototypes of each subtype or group, four main clades were clearly identified (Figure 3). The first clade, which included all of the French Guianan strains and the West and South African strains, corresponded to the cosmopolitan subtype (HTLV-I subtype A). In this clade, two molecular clusters could be distinguished among the strains from French Guiana. The first corresponded to Amerindian and Creole strains, which were closely similar to the strains of the Transcontinental subgroup A, whereas the second cluster was made up of strains from Noir-Marrons, which were closely related to the strains from the West African subgroup. Furthermore, comparison of the total LTR sequences of three strains from French Guiana with strains of other geographical origins confirmed the results of the gp21 env gene analysis (Talarmin et al., 1999). The first clade corresponded to the cosmopolitan group (HTLVI subtype A) and included the three strains from French Guiana. The strains from Amerindians and Creoles were found in the same cluster (Transcontinental subgroup), whereas the strain from the Noir-Marrons clustered with the Caribbean strains originating from West Africa (Gessain et al., 1992). These results suggest that HTLV-I infection was introduced recently to Amerindians in this area and that the Amerindian HTLV-I strains are of African origin.

Regarding HTLV-II, the comparative analyses of the nucleotide sequences of the gp21 env gene and LTR from the sole HTLV-II isolated from the Brazilian Amerindian women showed that this HTLV-II strain was of subtype A (Figure 4). However, sequence comparisons and phylogenetic analyses demonstrated that this HTLVII was closely related to a group of distinct variants of HTLV-II subtype A strains originating mostly from Brazilian inhabitants (Amerindian and intravenous drug users) and formerly called HTLV-II subtype C (Ishak et al., 1995), corre- sponding well to the Brazilian origin of the patient (Kazanji et al., 2001).

\section{The origin of HTLV-I infection in French Guiana}

The molecular epidemiology of various HTLVI strains from French Guiana indicates that Amerindian and Creole strains are closely related, suggesting a common origin for these strains. Concerning HTLV-I transmission, it is usually admitted that Amerindian populations have been infected through contacts with people from African origin after the slave trade (Gessain et al., 1996). However, it has recently been suggested that some Amerindian populations were infected with HTLV-I at the time of their migration to South America, since South American isolates are distinct from African strains (Li et al., 1999; Yamashita et al., 1998). Those authors report that the difference between their view and the prevailing view is in part due to differences in the genomic regions used for the phylogenetic analysis. Most researchers had previously used the env region, while Yamashita et al. (1998) used the LTR region. In our laboratory at the Pasteur Institute of French Guiana, both regions were sequenced (Talarmin et al., 1999), and the phylogenetic analysis of the $e n v$ gene showed that one Amerindian strain from Argentina is closer to strains from Noirs-Marrons than to strains from Amerindians in French Guiana. Furthermore, the comparison of a common portion of the LTR $(301 \mathrm{bp})$ of all strains from French Guiana and five Amerindian isolates from Argentina indicates that all these strains are closely related, suggesting a common origin (Talarmin et al., 1999). More recently, Li et al. (1999) showed the presence of HTLV-I in an Andean mummy, suggesting that the HTLV-I found there may be the aboriginal HTLV-I prevalent among Mongoloid populations in Asia and the Andes. The possibility of HTLV-I infection in ancient Andeans could be real. However, it is doubtful that the HTLV-I strains found in contemporary Indians are mostly derived from pre-Columbian Andeans as suggested by Li et al. (1999). Indeed, after comparing the LTR of HTLV-I found in Amerindians and other ethnic groups of African origin living in French Guiana, we have demonstrated that HTLV-I strains from Amerindians could not be distinguished from either those in French Guianan Creoles or inhabitants of the Andes in Argentina. All these strains have the same mutations as the Chilean strain CHI430 described by Li et al. 
Phylogenetic tree with a 522bp of the end of gp46 and most of gp21 in 60 HTLV-1 isolates, including 14 strains from French Guiana. Amerindian strains begin with AM, Creole strains with $C R$, and Noir-Marron strains with NM. Ptm3 (STLV-I isolate) was used to root the tree (modified from Talarmin et al., 1999). The numbers at some nodes (bootstrap values) represent the frequency of occurrence out of 500.

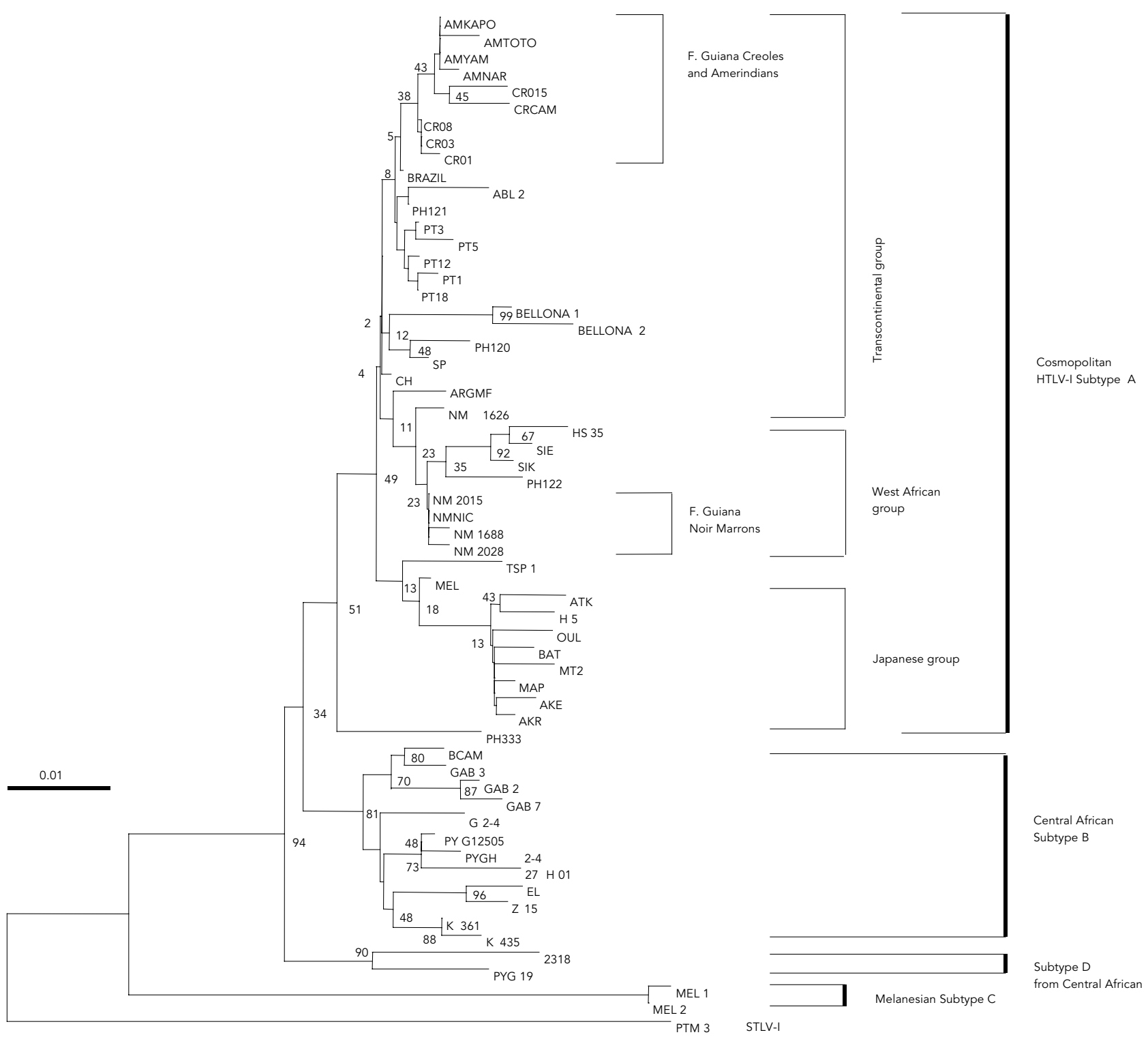


Figure 4

Phylogenetic tree with a 625-bp region of the HTLV-2 LTR. The sequence of HTLV-2 strain from French Guiana (GUY-II) was compared to 80 published sequences. The LTR of the STLV-2PP isolate was used as an outgroup to root the tree (modified from Kazanji et al., 2001). Bootstrap values were calculated for 500 trees.

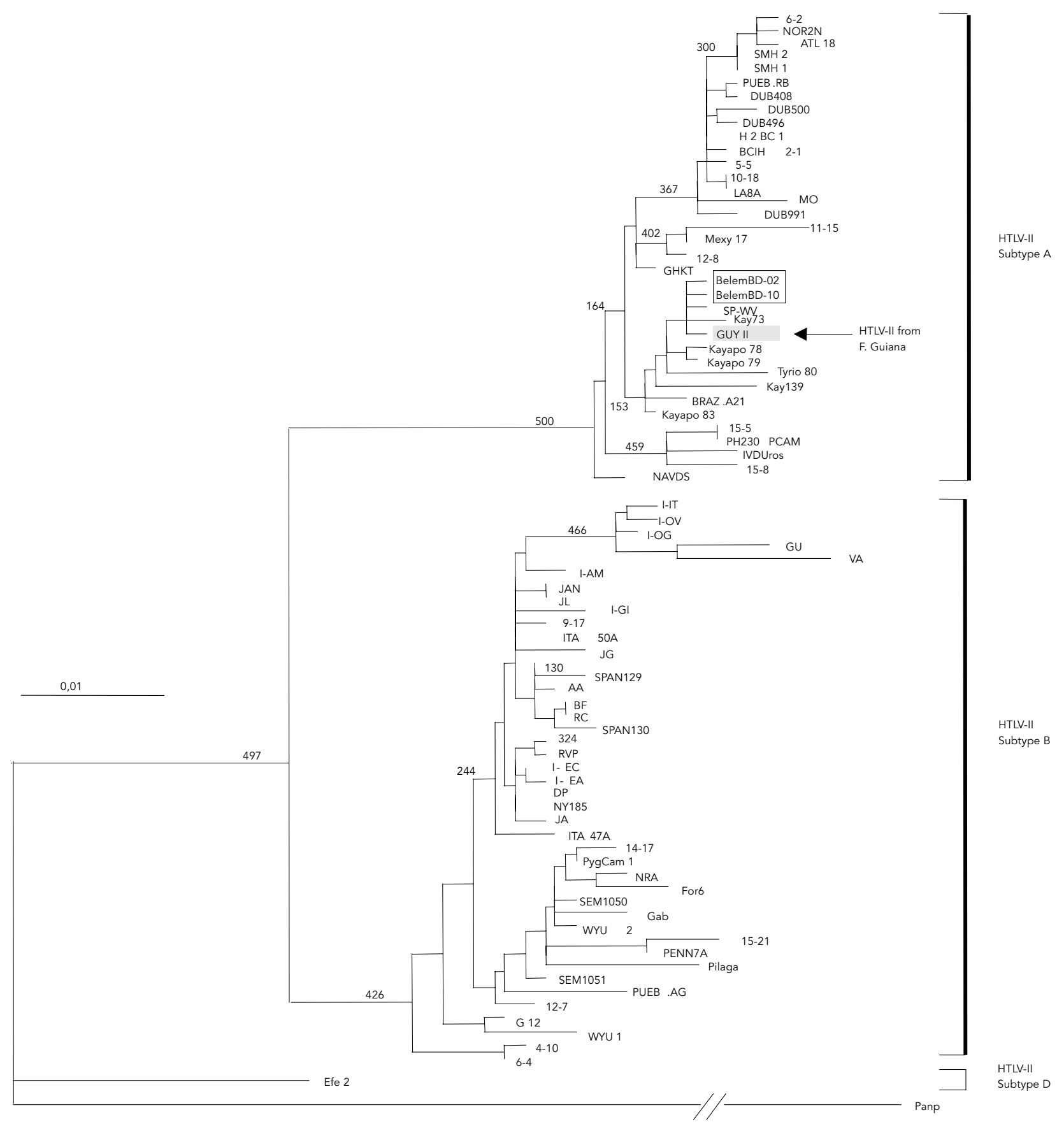


(1999), suggesting a common origin for all these strains. If the hypothesis of a pre-Columbian introduction is correct, Creoles would have to have been infected through sexual contact with Amerindians, and the introduction of the virus into this ethnic group would be more recent than that in Amerindians. If this were the case, since the risk factors for HTLV-I infection are at least as great among Amerindians and Creoles, the seroprevalence would be higher in Amerindians. However, the opposite is observed (Talarmin et al., 1999). Other factors led to the conclusion that HTLV-I was introduced recently among Amerindians in French Guiana. First, in the sero-epidemiological studies, the familial inquiry indicated that the HTLV-I-infected women had not been infected through breastfeeding, since their mothers were HTLVI-negative. Second, only a slight, non-significant increase was observed with age in the Amerindian groups in which HTLV-I was detected. This is unusual in populations in which HTLV-I is endemic (Plancoulaine et al., 1998). Third, if the virus had been introduced a long time ago, it would have been more prevalent. Therefore, the African origin of the Amerindian strains is very likely and is supported by recent results providing evidence for post-Colombian introduction of HTLV-I into Latin America (Van Dooren et al., 1998).

\section{Clinical studies of HTLV-I-associated diseases: adult T-cell leukemia, tropical spastic paraparesis/HTLV-I associated myelopathy, infective dermatitis, Strongyloides stercoralis infection, and other diseases}

Before we conducted our epidemiological studies, very few cases of ATL or TSP/HAM had been reported in patients from French Guiana. One of us had reported the presence of these HTLVI-associated diseases in patients living in metropolitan France, mainly the Paris area, but originating from French Guiana, and reported the main clinical and immunovirological characteristics (Gessain et al., 1990a, 1990b, 1990c).

An epidemiological study was thus initiated in 1990 to determine the prevalence, incidence, and main clinical characteristics of patients with ATL living in French Guiana (Gerard et al., 1995). All suspected cases of ATL were enrolled over 3 years, and their clinical, epidemiological, and immunovirological features were analyzed. Of the 19 suspected cases, 18 were considered to be ATL associated with HTLV-I. Eight of the patients presented with acute ATL leukemia- type, while eight had a lymphoma and two had a smoldering type. These prevalence rates are similar to those in clinical data from Japan and the Caribbean, where the leukemia type appears to predominate slightly. In some cases, a diagnosis of ATL is easily suspected on clinical and basic laboratory grounds. However, because of the wide diversity of the clinical presentation and evolution of the disease, the diagnosis must be confirmed (especially for some lymphoma and smoldering types) by immunological and molecular virology studies. Thus, only the demonstration of clonal integration of HTLV-I proviral DNA into the cutaneous lesions and/or lymph node can unambiguously differentiate specific skin tumors induced by HTLV-I from other cutaneous T-cell lymphomas such as Sézary syndrome, mycosis fungoides, and T-cell non-Hodgkin lymphoma, including those occurring in an HTLV-I seropositive carrier. In the 10-year period prior to this study, only two cases of ATL had been reported in French Guiana, indicating that the number of ATL cases is greatly underestimated in most tropical, HTLV-I endemic areas, such as South America and Africa. This underreporting appears to be due mainly to the acute nature of the disease, as patients often die before diagnosis can be made ( 15 patients died within 1 year of diagnosis in our study), but also to misdiagnosis of ATL as pathologically similar diseases such as Sézary syndrome, mycosis fungoides, and T-cell non-Hodgkin lymphoma. Furthermore, serological confirmatory tests for HTLV-I (such as Western blot) and/or molecular investigations are not readily available in most tropical countries. Although the number of patients was small, the average age of patients at the onset of the disease was much lower in the Noir-Marron population (38 years) than that reported in Japan (55-65) but is consistent with that described in some other series in the Caribbean area and South America (3650 years). From an epidemiological point of view, this preliminary study indicates that the crude incidence rate of ATL in French Guiana is around 3.5/100,000/year, a situation similar to that in the Caribbean and in HTLV-I-endemic regions of Japan. However, it was around 15$30 / 100,000$ /year (the highest incidence ever described) in a small group of African origin. This study, which is still ongoing, now includes more than 40 cases of ATL and confirms the initial findings (Gessain et al., unpublished data).

No data have been published on TSP/HAM in French Guiana, but preliminary studies indicate that it occurs mainly in the Creole population (Thévenot et al., unpublished data). 
One case of infective dermatitis has been seen in a young girl of Haitian origin infected with HTLV-I in Cayenne, and there have been a few cases of severe Strongyloides stercoralis infection associated with HTLV-I infection. The symptoms in this Haitian girl were mild, consisting essentially of centrofacial micropapules. Phenotypic analysis of the strain of Staphylococcus aureus isolated from dermatological lesions showed no production of leukocidin or exfoliation. The child presented symptomatic strongyloidiasis, which recurred despite multiple treatments (Clyti et al., in press). Furthermore, real-time quantitative PCR showed that this patient had a fivefold higher circulating HTLV-I proviral load than HTLV-I carriers, resulting from extensive proliferation of a restricted number of infected clones, i.e. oligoclonal expansion, as evidenced by semiquantitative amplification of HTLV-I flanking sequences (Gabet et al., 2000).

With respect to other clinical manifestations of HTLV-I infection in French Guiana, del Giudice et al. (1997) reported an association between ATL and crusted scabies in HTLV-I-infected patients. Four of six patients either had concomitant ATL when crusted scabies was diagnosed or developed ATL a few months later. The authors suggested that the occurrence of crusted scabies in patients seropositive for HTLV-I might represent a sign of marked immunosuppression related to ATL (del Giudice et al., 1997).

Finally, Talarmin et al. (1997) conducted an epidemiological study in French Guiana to determine whether nuclear antibodies were more frequent in HTLV-I carriers than in HTLV-Inegative individuals, and whether differences could be observed between the Creole and Noir-Marron populations in this regard. A total of 350 sera, with 175 from HTLV-I carriers (133 asymptomatic, 14 with TSP/HAM, and 24 with ATL) and 175 from controls, were screened for nuclear antibodies by immunofluorescence assays with HEp-2 cells. All sera with nuclear antibody titers $\geq 80$ were tested for autoantibodies against extractable nuclear antigens, histones, and double-stranded DNA. Nuclear antibodies (titers $\geq 80$ ) were detected in $13.1 \%$ of the HTLV-I carriers and $6.9 \%$ of the control group ( $\mathrm{p}<0.05)$. There was no difference in distribution by age, sex, or ethnic group and no difference, among HTLV-I carriers, between those who were asymptomatic and those with TSP/HAM or ATL. Most of the nuclear antibodies could not be characterized, but those of medical interest were found mainly in the HTLV-I-positive Creoles. The difference in the incidence of nuclear antibodies of medical interest between HTLV-I seropositive Creoles and Noir-Marrons was significant $(\mathrm{p}<0.04)$. However, the clinical significance of these nuclear antibodies in Creoles infected with HTLV-I remains to be demonstrated.

In conclusion, our long-term studies demonstrated clearly that some populations of French Guiana, especially those of African origin, are highly endemic for HTLV-I infection as well as for the severe associated diseases. Therefore, preventive measures to decrease spread and transmission of this human retrovirus are warranted. These include: (1) systematic HTLV-I screening of blood donors (this measure has been in effect in French Guiana since 1990); (2) systematic screening of pregnant women in order to counsel them concerning the risk of HTLV-I transmission by prolonged breastfeeding (this has been done since the early $1990 \mathrm{~s}$ in most of the cases); and (3) prevention of sexual transmission of HTLV-I by educational programs emphasizing the importance of using condoms to prevent all sexually transmitted diseases, including HIV infection, which is spreading rapidly in some of these populations. 


\section{Acknowledgments}

We are grateful to the medical staff of the different departments of French Guiana for allowing us to review their patients' medical records. We also thank Dr. Antoine Talarmin and the former directors of the Pasteur Institute of French Guiana (Drs. J.-P. Moreau and J.-L. Sarthou) for support and encouragement. We are grateful to Drs. Joëlle Sankale-Suzanon, André Lecante, and Michel Joubert for cooperation in this study. Finally, we also thank the Association pour la Recherche contre la Cancer (ARC), the Ministry of Research (Programme de Recherche Fondamentale en Microbiologie des Maladies Infectieuses et Parasitaires), Pasteur Institute, Paris, the International Network of the Pasteur Institute, and CORDET for their financial support.

\section{References}

BIGGAR, R. J.; TAYLOR, M. E.; NEEL, J. V.; HJELLE, B.; LEVINE, P. H.; BLACK, F. L.; SHAW, G. M.; SHARP, P. M. \& HAHN, B. H., 1996. Genetic variants of human T-lymphotropic virus type II in American Indian groups. Virology, 216:165-173.

BIGLIONE, M.; VIDAN, O.; MAHIEUX, R.; DE COLOMBO, M.; DE LOS ANGELES, M.; DE BASUALDO, A.; BONNET, M.; PANKOW, G.; AVILA-DE-EFRON, M.; ZORRILLA, A.; TEKAIA, F.; MURPHY, E.; DE THÉ, G. \& GESSAIN, A.,1999. Seroepidemiological and Molecular Studies of HTLV-II, subtype b, in isolated groups of Mataco and Toba Indians of Northern Argentina. AIDS Research and Human Retroviruses, 15:407-417.

BLACK, F. L.; BIGGAR, R. J.; NEEL, J. V.; MALONEY, E. M. \& WATERS, D. J., 1994. Endemic transmission of HTLV type II among Kayapo Indians of Brazil. AIDS Research and Human Retroviruses, 10:11651171.

CLYTI, E.; REYNIER, C.; COUPPIE, P.; KAZANJI, M.; SAINTE-MARIE, D.; PREVOST, G.; AZNAR, C. \& PRADINAUD, R., in press. Symptomatic infection with HTLV-1 in a child: Infective dermatitis associated with a recurrent strongyloidiasis. Annales de Dermatologie et de Vénérologie.

DE THE, G. \& BOMFORD, R., 1993. An HTLV-I vaccine: Why, how, for whom? AIDS Research and Human Retroviruses, 9:381-386.

DE THE, G.; GESSAIN, A.; GAZZOLO, L.; ROBERTGUROFF, M.; NAJBERG, G.; CALENDER, A.; PETI, M.; BRUBAKER, G.; BENSLIMAN, A. \& FABRY, F., 1985. Comparative seroepidemiology of HTLV-I and HTLV-III in the French West Indies and some African countries. Cancer Research, 45:4633s4636s.
DEL GIUDICE, P.; SAINTE MARIE, D.; GERARD, Y.; COUPPIE, P. \& PRADINAUD, R., 1997. Is crusted (Norwegian) scabies a marker of adult $\mathrm{T}$ cell leukemia/lymphoma in human $\mathrm{T}$ lymphotropic virus type I-seropositive patients? Journal of Infectious Diseases, 176:1090-1092.

DUBE, D. K.; SHERMAN, M. P.; SAKSENA, N. K.; BRYZ-GORNIA, V.; MENDELSON, J.; LOVE, J.; ARNOLD, C. B.; SPICER, T.; DUBE, S.; GLASER, J. B.; WILLIAMS, A.; NISHIMURA, M.; JACOBSEN, S.; FERRER, J.; DEL PINO, N.; QUIRELAS, S. \& POIESZ, B., 1993. Genetic heterogeneity in human T-cell leukemia/lymphoma virus type II. Journal of Virology, 67:1175-1184.

EIRAKU, N.; NOVOA, P.; DA COSTA-FERREIRA, M.; MONKEN, C.; ISHAK, R.; DA COSTA-FERREIRA, O.; ZHU, S. W.; LORENCO, R.; ISHAK, M.; AZVEDO, V.; GUERREIRO, J.; DE OLIVEIRA, M. P.; LOUREIRO, P.; HAMMERSCHLAK, N.; IJICHI, S. \& HALL, W. M., 1996. Identification and characterization of a new and distinct molecular subtype of human T-cell lymphotropic virus type II. Journal of Virology, 70:1481-1492.

FOUCHARD, N.; FLAGEUL, B.; BAGOT, M.; AVRIL, M. F; HERMINE, O.; SIGAUX, F.; MERLE-BERAL, H.; TROUSSARD, X.; DELFRAISSY, J. F.; DE THÉ, G. \& GESSAIN, A., 1995. Lack of evidence of HTLVI/II infection in T CD8 malignant or reactive lymphoproliferative disorders in France: a serological and/or molecular study of 169 cases. Leukemia, 9:2087-2092.

GABET, A. S.; MORTREUX, F; TALARMIN, A.; PLUMELLE, Y.; LECLERCQ, I.; LEROY, A.; GESSAIN, A.; CLITY, E.; JOUBERT, M. \& WATTEL, E., 2000. High circulating proviral load with oligo- 
clonal expansion of HTLV-1 bearing T cells in HTLV-1 carriers with strongyloidiasis. Oncogene, 19:4954-4960.

GERARD, Y.; LEPERE, J. F.; PRADINAUD, R.; JOLY, F.; LEPELLETIER, L.; JOUBERT, M.; SAINTE MARIE, D.; MAHIEUX, R.; VIDAL, A. U.; LARREGAINFOURNIER, D.; VALENSI, F.; MOYNET, D.; DE THÉ, G.; GUILLEMAIN, B.; MOREAU, J. P. \& GESSAIN, A., 1995. Clustering and clinical diversity of adult T-cell leukemia/lymphoma associated with HTLV-I in a remote black population of French Guiana. International Journal of Cancer, 60:773776.

GESSAIN, A., 1996. Epidemiology of HTLV-I and associated diseases. In: Human T-cell Lymphotropic Virus Type 1 (P. Höllsberg \& D. A. Hafler, ed.), pp. 33-64, Chichester: John Wiley \& Sons.

GESSAIN, A.; BARIN, F.; VERNANT, J. C.; GOUT, O.; MAURS, L.; CALENDER, A. \& DE THÉ, G., 1985. Antibodies to human T-lymphotropic virus type-I in patients with tropical spastic paraparesis. Lancet, 2:407-410.

GESSAIN, A.; CALENDER, A.; STROBEL, M.; LEFAITROBIN, R. \& DE THE, G., 1984. High prevalence of antiHTLV- 1 antibodies in the Boni, an ethnic group of African origin isolated in French Guiana since the 18th century. Comptes Rendus de l'Académie des Sciences, 299:351-353.

GESSAIN, A.; GALLO, R. C. \& FRANCHINI, G., 1992. Low degree of human T-cell leukemia/lymphoma virus type I genetic drift in vivo as a means of monitoring viral transmission and movement of ancient human populations. Journal of Virology, 66:2288-2295.

GESSAIN, A.; GOUT, O.; SAAL, F.; DANIEL, M.; RIO, B.; FLANDRIN, G.; SIGAUX, F.; LYON-CAEN, O.; PERIES, J. \& DE THE, G., 1990a. Epidemiology and immunovirology of human T-cell leukemia/ lymphoma virus type I-associated adult T-cell leukemia and chronic myelopathies as seen in France. Cancer Research, 50:5692S-5696S.

GESSAIN, A.; MAHIEUX, R. \& DE THÉ, G., 1996. Genetic variability and molecular epidemiology of human and simian $\mathrm{T}$ cell leukemia/lymphoma virus type I. Journal of Acquired Immune Deficiency Syndromes and Human Retrovirology, 13 (Sup. 1):S132-145.

GESSAIN, A.; MEERTENS, L. \& MAHIEUX, R., 2002. Molecular epidemiology of human T cell leukemia/ lymphoma viruses type I and type II (HTLV-I/II) and related simian retroviruses (STLV-I, STLV-II and STLV-L/III). In: The Molecular Epidemiology of Human Viruses (T. Leitner, ed.), pp. 121-165, Boston: Kluwer Academic Publishers.

GESSAIN, A.; SAAL, F.; GIRON, M.; LASNERET, J.; LAGAYE, S.; GOUT, O.; DE THE, G.; SIGAUX, F. \& PERIES, J., 1990b. Cell surface phenotype and human $\mathrm{T}$ lymphotropic virus type 1 antigen expression in $12 \mathrm{~T}$ cell lines derived from peripheral blood and cerebrospinal fluid of West Indian, Guyanese and African patients with tropical spastic paraparesis. Journal of General Virology, 2:333341.

GESSAIN, A.; SAAL, F.; GOUT, O.; DANIEL, M.; FLANDRIN, G.; DE THE, G.; PERIES, J. \& SIGAUX, F., 1990c. High human T-cell lymphotropic virus type I proviral DNA load with polyclonal integration in peripheral blood mononuclear cells of French West Indian, Guianese, and African patients with tropical spastic paraparesis. Blood, 15:428-433.

GOTUZZO, E.; ARANGO, C.; DE QUEIROZ-CAMPOS, A \& ISTURIZ, R. E., 2000. Human T cell lymphotropic virus-I in Latin America. Infection Diseases Clinical of North America, 14:211-239.

GRENAND, P. \& GRENAND, F., 1990. Les Amérindiens: Des Peuples pour la Guyane de Demain. Cayenne: Centre ORSTOM Cayenne.

HALL, W. W.; ISHAK, R.; ZHU, S. W.; NOVOA, P.; EIRAKU, N.; TAKAHASHI, H.; FERREIRA, M. D. C.; AZEVEDO, V.; ISHAK, M. O.; FERREIRA, O. D. C.; MONKEN, C. \& KURATA, T., 1996. Human T lymphotropic virus type II (HTLV-II): Epidemiology, molecular properties, and clinical features of infection. Journal of Acquired Immune Deficiency Syndromes and Human Retrovirology, 13(Sup. 1):S204-214.

HALL, W. W.; TAKAHASHI, H.; LIU, C.; KAPLAN, M. H.; SCHEEWIND, O.; IJICHI, S.; NAGASHIMA, K. \& GALLO, R. C., 1992. Multiple isolates and characteristics of Human T-Cell Leukemia Virus Type-II. Journal of Virology, 66:2456-2463.

HJELLE, B.; APPENZELLER, O.; MILLS, R.; ALEXANDER, S.; TORREZMARTINEZ, N.; JAHNKE, R. \& ROSS, G., 1992. Chronic neurodegenerative disease associated with HTLV-II infection. Lancet, 339:645-646.

HJELLE, B.; MILLS, R.; SWENSON, S.; MERTZ, G.; KEY, C. \& ALLEN, S., 1991. Incidence of hairy cell leukemia, mycosis fungoides, and chronic lymphocytic leukemia in first known HTLV-II-endemic population. Journal of Infectious Diseases, 163:435-440.

HJELLE, B.; ZHU, S. W.; TAKAHASHI, H.; IJICHI, S. \& HALL, W. W., 1993. Endemic human T cell leukemia virus type II infection in southwestern US Indians involves two prototype variants of virus. Journal of Infectious Diseases, 168:737-740.

IJICHI, S.; MATSUDA, T.; MARUYAMA, I.; IZUMIHARA, T.; KOJIMA, K.; NIIMURA, T.; MARUYAMA, Y.; SONODA, S.; YOSHIDA, A. \& OSAME, M., 1990. Arthritis in a Human T-Lymphotropic Virus TypeI (HTLV-I) Carrier. Annals of the Rheumatic Diseases, 49:718-721.

IJICHI, S.; TAJIMA, K.; ZANINOVIC, V.; LEON, F. E.; KATAHIRA, Y.; SONODA, S.; MIURA, T.; HAYAMI, M. \& HALL, W. W., 1993. Identification of human $\mathrm{T}$ cell leukemia virus type IIb infection in the Wayu, an aboriginal population of Colombia. Japanese Journal of Cancer Research, 84:12151218.

ISHAK, R.; HARRINGTON, W. J. J.; AZEVEDO, V. N.; EIRAKU, N.; ISHAK, M. O.; GUERREIRO, J. F.; SANTOS, S. B.; KUBO, T.; MONKEN, C. \& ALEXANDER, S., 1995. Identification of human T cell lymphotropic virus type IIa infection in the Kayapo, an indigenous population of Brazil. AIDS Research and Human Retroviruses, 11:813-821.

KAZANJI, M.; BENOIT, B.; MEDDEB, M.; MEERTENS, L.; MARTY, C.; GESSAIN, A. \& TALARMIN, A., 2001. Molecular characterization and phylogenetic analysis of a human $\mathrm{T}$ cell leukemia virus 
type II strain from French Guiana. AIDS Research and Human Retroviruses, 17:563-568.

LAGRENADE, L.; HANCHARD, B.; FLETCHER, V.; CRANSTON, B. \& BLATTNER, W., 1990. Infective dermatitis of Jamaican children - A marker for HTLV-I infection. Lancet, 336:1345-1347.

LAIRMORE, M. D.; JACOBSON, S.; GRACIA, F.; DE, B. K.; CASTILLO, L.; LARREATEGUI, M.; ROBERTS, B. D.; LEVINE, P. H.; BLATTNER, W. A. \& KAPLAN, J. E., 1990. Isolation of human T-cell lymphotropic virus type-2 from Guaymi Indians in Panama. Proceedings of the National Academy of Sciences of United States of America, 87:8840-8844.

LEE, H.; IDLER, K. B.; SWANSON, P.; APARICIO, J. J.; CHIN, K. K.; LAX, J. P.; NGUYEN, M.; MANN, T.; LECKIE, G.; ZANETTI, A.; MARINUCCI, G.; CHEN, I. \& ROSENBLATT, J., 1993. Complete nucleotide sequence of HTLV-II isolate NRA: Comparison of envelope sequence variation of HTLV-II isolates from U.S. blood donors and U.S. and Italian i.v. drug users. Virology, 196:57-69.

LEE, H.; SWANSON, P.; SHORTY, V. S.; ZACK, J. A.; ROSENBLATT, J. D. \& CHEN, I. S., 1989. High rate of HTLV-II infection in seropositive IV drug abusers in New Orleans. Science, 244:471-475.

LEVINE, P. H.; JACOBSON, S.; ELLIOTT, R.; CAVALlERO, A.; COLClOUGH, G.; DORRY, C.; STEPHENSON, C.; KNIGGE, R. M.; DRUMMOND, J.; NISHIMURA, M.; TAYLOR, M.; WIKTOR, S. \& SHAW, G., 1993. HTLV-II infection in Florida Indians. AIDS Research and Human Retroviruses, 9: 123-127.

LI, H. C.; FUJIYOSHI, T.; LOU, H.; YASHIKI, S.; SONODA, S.; CARTIER, L.; NUNEZ, L.; MUNOZ, I.; HORAI, S. \& TAJIMA, K., 1999. The presence of ancient human T-cell lymphotropic virus type I provirus DNA in an Andean mummy. Nature Medicine, 5:1428-1432.

MOCHIZUKI, M.; YAMAGUCHI, K.; TAKATSUKI, K.; WATANABE, T.; MORI, S. \& TAJIMA, K., 1992. HTLVI and Uveitis. Lancet, 339:1110.

MORGAN, O.; RODGERS-JOHNSON, P.; MORA, C. \& CHAR, G., 1989. HTLV-I and polymyositis in Jamaica. Lancet, 2:1184-1186.

MURPHY, E. L.; FRIDEY, J.; SMITH, J. W.; ENGSTROM, J.; SACHER, R. A.; MILLER, K.; GIBBLE, J.; STEVENS, J.; THOMSON, R.; HANSMA, D.; KAPLAN, J.; KHABBAZ, R. \& NEMO, G., 1997. HTLVassociated myelopathy in a cohort of HTLV-I and HTLV-II-infected blood donors. The REDS investigators. Neurology, 48:315-320.

MURPHY, E. L.; MAHIEUX, R.; DE THÉ, G.; TEKAIA, F.; AMETI, D.; HORTON, J. \& GESSAIN, A., 1998. Molecular epidemiology of HTLV-II among United States blood donors and intravenous drug users: An age-cohort effect for HTLV-II RFLP type aO. Virology, 242, 425-434.

PARDI, D.; SWITZER, W. M.; HADLOCK, K. G.; KAPLAN, J. E.; LAL, R. B. \& FOLKS, T. M., 1993. Complete nucleotide sequence of an Amerindian human T-cell lymphotropic virus type II (HTLV-II) isolate: identification of a variant HTLV-II subtype b from a Guaymi Indian. Journal of Virology, 67:4659-4664.

PLANCOULAINE, S.; BUIGUES, R. P.; MURPHY, E.; VAN BEVEREN, M.; POULIQUEN, J. F.; JOUBERT,
M.; REMY, F.; TUPPIN, P.; TORTEVOYE, P.; DE THÉ, G.; MOREAU, J. P. \& GESSAIN, A., 1998. Demographic and familial characteristics of HTLVI infection among an isolated, highly endemic population of African origin in French Guyana. International Journal of Cancer, 76:331-336.

PLANCOULAINE, S.; GESSAIN, A.; JOUBERT, M.; TORTEVOYE, P.; JEANNE, I.; TALARMIN, A.; DE THE, G. \& ABEL, L., 2000. Detection of a major gene predisposing to human $\mathrm{T}$ lymphotropic virus type I infection in children among an endemic population of African origin. Journal of Infectious Diseases, 182:405-412.

POIESZ, B. J.; RUSCETTI, F. W.; GAZDAR, A. F.; BUNN, P. A.; MINNA, J. D. \& GALLO, R. C., 1980. Detection and isolation of type-C retrovirus particles from fresh and cultured lymphocytes of a patient with cutaneous T-cell lymphoma. Proceedings of the National Academy of Sciences of United States of America, 77:7415-7419.

SALEMI, M.; VANDAMME, A.; GRADOZZI, C.; VAN LAETHEM, K.; CATTANEO, E.; TAYLOR, G.; CASOLI, C.; GOUBAU, P.; DESMYTER, J. \& BERTAZZONI, U., 1998. Evolutionary rate and genetic heterogeneity of human T-cell lymphotropic virus type II (HTLV-II) using isolates from European injecting drug users. Journal of Molecular Evolution, 46:602-611.

SCHWEBKE, J.; CALSYN, D.; SHRIVER, K.; SAXON, A.; KLEYN, J.; OLUOCH-MITCHELL, E.; OLMSTEAD, L.; FISHER, L. D.; KRONE, M.; ASHLEY, R.; STAMM, W.; SWENSON, P. \& HOLMES, K. K., 1994. Prevalence and epidemiologic correlates of human $\mathrm{T}$ cell lymphotropic virus infection among intravenous drug users. Journal of Infectious Diseases, 169:962-967.

SHINDO, N.; ALCANTARA, L. C.; VAN DOOREN, S.; SALEMI, M.; COSTA, M. C.; KASHIMA, S.; COVAS, D. T.; TEVA, A.; PELLEGRINI, M.; BRITO, I.; VANDAMME, A. M. \& GALVÃO-CASTRO, B., 2002. Human retroviruses (HIV and HTLV) in Brazilian Indians: Seroepidemiological study and molecular epidemiology of HTLV type II isolates. AIDS Research and Human Retroviruses, 18:71-77.

SLATTERY, J. P.; FRANCHINI, G. \& GESSAIN, A., 1999. Genomic evolution, patterns of global dissemination, and interspecies transmission of human and simian T-cell leukemia/lymphotropic viruses. Genome Research, 9:525-540.

SORIANO, V.; CALDERON, E.; ESPARZA, B.; CILLA, G.; AGUILERA, A.; GUTIERREZ, M.; TOR, J.; PUJOL, E.; MERINO, F.; PEREZ-TRALLERO, E.; LEAL, M. \& GONZALEZ-LAHOZ, J., 1993. HTLV-I/II infections in Spain. The HTLV-I/II Spanish Study Group. International Journal of Epidemiology, 22:716-719.

SWITZER, W. M.; BLACK, F. L.; PIENIAZEK, D.; BIGGAR, R. J.; LAL, R. B. \& HENEINE, W., 1996. Endemicity and phylogeny of the human T cell lymphotropic virus type II subtype A from the Kayapo Indians of Brazil: Evidence for limited regional dissemination. AIDS Research and Human Retroviruses, 12:635-640.

SWITZER, W. M.; OWEN, S. M.; PIENIAZEK, D. A.; NERURKAR, V. R.; DUENAS-BARAJAS, E.; HENEINE, W. \& LAL, R. B., 1995. Molecular analysis of human T-cell lymphotropic virus type II 
from Wayuu Indians of Colombia demonstrates two subtypes of HTLV-IIb. Virus Genes, 10:153162.

TALARMIN, A.; NIZOU, J. Y. \& KAZANJI, M., 1997. Antinuclear autoantibodies in human T-cell leukemia/ lymphoma virus type I carriers in French Guiana. Archives of Virology, 142:1713-1718.

TALARMIN, A.; VION, B.; URETA-VIDAL, A.; DU FOU, G.; MARTY, C. \& KAZANJI, M., 1999. First seroepidemiological study and phylogenetic characterization of human T-cell lymphotropic virus type I and II infection among Amerindians in French Guiana. Journal of General Virology, 80:3083-3088. TORTEVOYE, P.; TUPPIN, P.; PENEAU, C.; CARLES, G. \& GESSAIN, A., 2000. Decrease of human T-cell lymphotropic virus type I prevalence and low incidence among pregnant women from a high endemic ethnic group in French Guiana. International Journal of Cancer, 87:534-538.

TUPPIN, P.; LEPERE, J. F.; CARLES, G.; URETA-VIDAL, A.; GERARD, Y.; PENEAU, C.; TORTEVOYE, P.; DE THÉ, G.; MOREAU, J. P. \& GESSAIN, A., 1995. Risk factors for maternal HTLV-I infection in French Guiana: High HTLV-I prevalence in the Noir Marron population. Journal of Acquired Immune Deficiency Syndromes and Human Retrovirology, 8:420-425.
URETA-VIDAL, A.; ANGELIN-DUCLOS, C.; TORTEVOYE, P.; MURPHY, E.; LEPERE, J. F.; BUIGUES, R. P.; JOLLY, N.; JOUBERT, M.; CARLES, G.; POULIQUEN, J. F.; DE THE, G.; MOREAU, J. P. \& GESSAIN, A., 1999. Mother-to-child transmission of human T-cell-leukemia/lymphoma virus type I: Implication of high antiviral antibody titer and high proviral load in carrier mothers. International Journal of Cancer, 82:832-836.

VAN DOOREN, S.; GOTUZZO, E.; SALEMI, M.; WATTS, D.; AUDENAERT, E.; DUWE, S.; ELLERBROK, H.; GRASSMANN, R.; HAGELBERG, E.; DESMYTER, J. \&VANDAMME, A. M., 1998. Evidence for a postColumbian introduction of human T-cell lymphotropic virus in Latin America. Journal of General Virology, 79:2695-2708.

YAMASHITA, M.; PICCHIO, G.; VERONESI, R.; OHKURA, S.; BARE, P. \& HAYAMI, M., 1998. HTLV-Is in Argentina are phylogenetically similar to those of South American countries, different from HTLVIs in Africa. Journal of Medical Virology, 55:152160.

Submitted on October 14, 2002

Final version resubmitted on March 25, 2003

Approved on April 28, 2003 